\title{
SECOND-HAND AND ANTIQUARIAN BOOKS ON THE INTERNET
}

THIS ARTICLE IS A DISTILLATION of thousands of conversations held over the past six years or so with collectors, dealers, and librarians about the buying and selling of second-hand and antiquarian books online. It was a gripping topic in 1995 and remains so in 2001. The ability to acquire books via the Internet has, after all, profoundly affected the professional lives of librarians and book dealers and has radically changed the face of both personal and institutional collecting. There is still much to talk about: The ground continues to shift beneath our feet as online book sites, originally an American phenomenon, spread to Europe and elsewhere, daily increasing the size and complexity of this vast, virtual Internet bookstore, engendering new models of bookselling and new patterns of collecting. The Internet book trade is, admittedly, barely half a decade old, but five years translates to something like an age in computer terms, and it is not too early to pause and consider how it all began and where things stand today.

A useful chronology of antiquarian and second-hand bookselling on the Internet can be developed from the online archive of the Exlibris electronic discussion group. Exlibris, founded to provide "an environment for discussing matters related to rare book and manuscript librarianship, including special collections and related issues," was established in 1990 at Rutgers University by Peter S. Graham and has been moderated by Everett Wilkie since 1995. The searchable archive of the list begins in April, 1991. In the early years of Exlibris, messages concerning the buying 
and selling of rare books were scant. Few dealers were subscribed at first, and postings of a commercial nature were discouraged. In early 1993, this policy was relaxed somewhat, and announcements about the availability of printed catalogs began to appear later that year. By the spring of the following year, entire catalogs (Quarto Books and the Heldfond Gallery were two pioneers) were being posted to the list. On May 3, 1994, responding to complaints about this practice, which tended to clog the email in-boxes of some recipients, David L. Gants proposed the following:

While most readers of ex-libris [sic] agree on the desirability of having on-line catalogs, none want their mail queues swamped with waves of 400-line postings. Perhaps the recent explosion of interest in the World Wide Web and its graphic interfaces (such as Mosaic) offer a possible solution. If book dealers interested in creating Internet-accessible catalogs banded together to purchase a commercial Internet account, they could set-up a Web site containing quite sophisticated listings... Aside from the ability to present both text and image, these Web catalogs would be passive-all files would reside at the node owned by the consortium of booksellers and would not clog our mail queues.

On the following day, Edward Ripley-Duggan, proprietor of Wilsey Rare Books, replied:

The ABAA [Antiquarian Booksellers Association of America] is examining the issue of Internet access for its members, an increasing number of whom use on-line services (such as RLIN and OCLC), and are therefore familiar with communications technology. As yet, few booksellers use the Internet, but that is changing rapidly, as witness recent postings here. The idea of passive catalogs residing at the ABAA node is a good one, though it may be a little while before it comes to pass.

Gants's posting was prophetic, and the kind of site he envisioned "came to pass" sooner than he or Ripley-Duggan (or anyone else, for that 
matter) could have guessed. In fact, the first book search database was born just about the time of Gants's speculative posting. Interloc (later reincarnated as Alibris in 1998) was a subscription service that gave access, for a fee, to the stocks of participating booksellers. Subscribers sent lists of wants via e-mail to the Interloc computer system, which matched the items wanted with those listed for sale in its database. Successful matches were e-mailed to subscribers the next morning. In July 1994, after ten weeks of operation, Interloc reported on Exlibris a subscription base of 225 customers and nearly 300,000 items in its books database. Although revolutionary for its time, the Interloc model of noninteractive, fee-based searches had only limited appeal for pioneers of the Web and was soon scrapped.

Fueled by the same advances in search engine technology that were driving development of the Web itself, the growth of free, interactive, graphics-intensive book search sites was explosive. In February, 1995, the ABAA established a site linking 448 ABAA dealers. Initially, the site did not allow individual title searches, but dealer Web sites could be ranked by specialty. Advance Book Exchange (ABE), Bibliocity, and Bibliofind were all launched in 1996, each offering searches of hundreds of dealer databases by author, title, and keyword. Bibliocity was eventually absorbed by Alibris, and Bibliofind may undergo a similar transformation as a result of its recent merger with Amazon.com. In the past two years, these original sites have been joined by many others: Antiqbook, Biblion, BiblioRoom, BookAvenue, International League of Antiquarian Booksellers/La Ligue Internationale de la Librairie Ancienne (ILAB/LILA) site, JustBooks, Half.com, Powell's Books, TomFolio, and WorldBookDealers.com, to name just a few.

American dealers predominated on these sites at first, but the geographical coverage today is happily much broader. Virtually all the book search sites now represent dealers from around the world WorldBookDealers.com makes a special point of this), but some have a distinct national or regional 
focus: Biblion (British bookdealers exclusively); the French sites Galaxidion and the book component of France Antiques; LibriAntichi, indexing Italian dealers; Antiqbook (the Netherlands Antiquarian Booksellers' Network); the ILAB/LILA site; and JustBooks, which maintains separate French, English, and German sites.

The proliferation of book sites can make searching a daunting task. Bookfinder (originally MXBookfinder) was organized in 1997 to index the other major book sites, allowing a single search to return hits from multiple databases. In 1997, there were only three such sites: ABE, Bibliofind, and Bibliocity; in 2001, BookFinder covers nine secondhand/antiquarian book search databases. AddAll, another book search "super-site" founded in 1998, currently indexes ten.

Keeping in mind that many of the same dealers (and their stock) are found on multiple sites, the number of titles reportedly for sale at any one time is nevertheless mind-boggling. ABE currently claims links to seven thousand booksellers and more than 24 million volumes; Bibliofind claims "thousands" of dealers and "over 20 million" books. (By way of comparison, a single issue of $A B$ Bookman's Weekly in its heyday might have contained seven thousand titles for sale.) In terms of price, titles offered for sale fall overwhelmingly into a moderate range of $\$ 25$ to $\$ 250$. A recent, highly unscientific search of $A B E$, for example, sorted by price, brought up only a few titles priced above $\$ 100,000$ and only about 50 priced between $\$ 10,000$ and $\$ 100,000$ this out of an online "stock" of several million books.

Book auction activity rivals online catalog sales. Founded in 1995, eBay was the first major venue for online book auctions and is still by far the most active. A recent count showed more than 320,000 books up for bid on a single day, of which almost 18,000 were categorized as "Antiquarian, Rare" and more than 13,000 as "First Editions." A check of the Amazon.com book auction site turned up a total of 19,000 items 
categorized as "rare." Book auctions on eBay and Amazon.com are, of course, comparatively undisciplined affairs: Neither site monitors the quality or condition of items sold, and description, illustration, pricing, and so on are entirely the responsibility of hundreds of thousands of individual consignors. Levels of knowledge, experience, and honesty naturally vary widely across this population-caveat most certainly emptor. The much lower level of Internet activity at established houses (Sotheby's Web site on a recent day had only 588 titles up for bid, and Pacific Book Auctions, 272) reflects the fact that items for sale are professionally vetted and described. As with the book search sites, books up for Internet auction (this is particularly true at eBay and Amazon.com) very seldom go above the $\$ 10,000$ mark, with the vast majority knocked down to under $\$ 500$.

The rapid growth and continuing popularity of online bookseller and book auction sites is due to the fact that they can place the right book into the hands of the right customer with a speed and ease impossible a decade ago. Super-sites such as Bookfinder.com electronically combine the stocks of thousands of individual dealers to create vast online bookstores containing millions of volumes; eBay and Amazon.com mount virtual auctions whose lots number in the hundreds of thousands. The combined virtual catalog of these sites is updated minute by minute and is available 24 hours a day, seven days a week, 365 days a year-"all books, all the time." The consequences for anyone who regularly buys or sells books are enormous-for better or for worse.

Prior to the mid-1990s, acquiring a scarce second-hand book necessarily meant days, months, or even years of effort, visiting dealers, poring over catalogs, or placing orders through an out-of-print search service. A good many of these services advertised the wants of their customers through printed ads in $A B$ Bookman's Weekly, and it is worth digressing here to note how exactly the rise in popularity of online book sales parallels the decline of the revered $A B$. In 1994, the average issue of $A B$ 
had 112 pages, including about 50 pages of "Books Wanted" and about 36 pages of "Books for Sale." Unwilling or unable to compete with the online sites, the magazine shrank steadily in volume throughout the 1990s; and by December, 1999, issues were running at 32 pages each, with only six pages of "Books Wanted" and ten pages of "Books for Sale." The demise of AB Bookman's Weekly was announced on Exlibris shortly thereafter, on January 25, 2000.

The benefits of the new technology are undeniable: A librarian, finding that his or her collection lacks a certain title, now routinely goes online and locates and orders a copy through the book search databases. A process that five years ago might have taken anywhere from six weeks to six years to complete successfully now can be accomplished (with luck) in a few minutes. The large numbers of books available often allow choice among multiple copies, based on condition and price.

Similarly, a collector sitting down to use the book search databases for the first time finds at a stroke nearly half of the titles on her "musthave" list, some of which have eluded her for 25 years. A fellow collector (who also happens to be a bibliographer), embarking on what was supposed to be a lifetime project, finds after five years that he has acquired via the Internet almost 90 percent of his primary source material, aided by automatic notification features available through the book search and book auction sites that keep him informed of all new additions to the databases in his field of interest. He has begun several subcollections supporting his main interest. The sheer mass of material available on the Internet, ordered by means of sophisticated search engines, makes possible the rapid assembly even of extremely focused collections. Although the Internet has certainly brought masses of hitherto obscure and unregarded material to light, and to some extent fostered a market for such material, traditionally scarce and desirable materials have not become more common: the Internet has not brought to light unrecorded copies of the Bay Psalm Book. 
One antiquarian bookseller claims that she still does most of her high-end business via printed catalogs or word-of-mouth. Rare and costly books advertised on the Internet, she claims, generate lots of time-consuming email correspondence, but few sales. She admits, however, that nearly all her stock in the $\$ 50$ to $\$ 75$ range is sold via the book search sites and that 40 percent of her total sales are made online. At one time, it was thought that the growth of Internet book sales would make printed catalogs obsolete, but in fact, there seem to be more (and higher-quality) printed catalogs produced now than ten years ago. To a certain rural second-handbook dealer, however, the Internet is a godsend. Ten years ago, he depended on seasonal tourist traffic, very occasional mail-order sales, and regional book fairs. The book sites now allow him to sell books steadily year-round, and he estimates that nearly 75 percent of his yearly revenue now comes from Internet sales. Booksellers can now sell stock in weeks that may in past times have taken months, years, or even decades to move. In general, booksellers find that the ability to sell at any time to anyone in any place via the Internet significantly increases the profitability of their business. And, of course, private individuals now also can offer books for sale through Internet auction sites and potentially realize something close to retail prices.

Chucking the old order does not automatically bring about Utopia, however. The enormous scale and freewheeling nature of the Internet "virtual bookstore" can be a curse as well as a blessing. Those who buy regularly on the Internet-dealers as well as collectors-are all-tooconscious of a certain lack of standardization in descriptions of items for sale. Our librarian, for instance, finds that the ease and speed with which he can now acquire books is offset somewhat by the frustrating fact that, upon arrival, the books are often found to be not quite as described. Our collector is overjoyed at the number of scarce titles she finds on the Internet but also finds it difficult to judge the relative merits of the copy from dealer X in "good condition" for $\$ 15$, the copy 
from dealer Y described as in "pretty good shape" at $\$ 17$, and the copy from dealer Z listed as "well-loved" for $\$ 13.50$. And sometimes lack of expertise on the seller's part is matched by lack of experience and savvy on the buyer's part. A novice Internet user, looking for a copy of a favorite childhood storybook to give to her young daughter, is delighted to find it on eBay. Unfortunately, the artfully imprecise phrase "in good condition for its age" sets off no mental alarm bells, and she is less delighted to learn that it can (and in this case, does) mean "soiled, shaken, and lacking rear cover." Moreover, maintenance problems are inherent in any very large database. Our collector/bibliographer, though well aware of the advantages of the Internet, is irritated to find that books sold months or even years earlier continue to be offered for sale. Another irritant is the high rate of duplication of copies across book search sites. Many dealers belong to multiple sites, which means that a search through BookFinder, AddAll, or one of the other super-sites can bring up four or five citations for the same copy.

Dealers on the Internet, particularly those dealers who began their careers before the Internet age, report dissatisfactions of a less tangible kind. They mourn the demise of the traditional storefront, which has meant a decline in personal contact between collector and dealer and a consequent loss of opportunities for mutual education. Collectors, they say, are becoming more isolated. This may be true, but it is unclear what role the Internet plays in the process. It might be argued that buying a book on the Internet is not fundamentally different from buying one through a printed catalog and therefore is not necessarily more destructive of the dealer-collector relationship.

Book historians are (or ought to be) concerned that the history of this enormous Internet bookselling venture appears to be writ in water: There is no central archive of these transactions, no online version of either American Book Prices Current or Bookman's Price Index, and no 
record of what titles have been offered at what prices. EBay alone offers a search of completed auction items, but only for sales ending within the previous few days. Book scholarship depends heavily on sale records to trace provenance and document trends in collecting, and the complete absence of such records has grave long-term consequences for this branch of historical research.

There have been some disturbing developments in recent years. In preInternet days, out-of-print search services imposed a hefty markup on the books they located for their customers. Fair enough. They paid for the advertisements in $A B$ Bookman's Weekly and elsewhere, they searched the catalogs, and otherwise did the legwork. One of the attractions of the online book search engine, however, was that it eliminated the middleman and his or her fee. Using ABE, Bibliofind, or one of the other sites, even the most inexperienced book buyer could now make direct contact with a dealer and save money as well as time. Some sites, not content with subscription fees from individual dealers, are now adding a processing fee to the price of each book, typically 20 percent, and are withholding customer access to dealers in order to safeguard it. The fee reportedly covers (among other things) single invoicing for multiple titles ordered from several dealers, conceivably an attractive proposition for acquisitions departments of major libraries. The benefit to the private collector is less clear, but customers of these sites cannot opt to forego the charge, even if they have no need of services such as "centralized inspection" of books, vast warehouses and their staff, and the like. Fortunately, most of the dealers who subscribe to fee-based sites retain membership in the free ones, and the savvy book buyer searching the Internet via a super-site such as BookFinder or AddAll can simply avoid titles listed through fee-based search services-at least for now. Bibliocity was the first database to be absorbed by a fee-based service. If enough others follow, a major Internet resource will be compromised, for not only will customers pay more for books, they will lose personal contact with 
dealers - a greater calamity by far for both dealers and collectors.

One can only speculate about the future. Who, ten years ago, could have predicted the size, the complexity, the international scope of Internet bookselling today? One expects that the phenomenon will continue to develop along certain lines-that more dealers will come online; that dealer databases will become more sophisticated and perhaps include more illustrations; and that search engines will grow more powerful and comprehensive to the point where any and every title online is accessible through a single search engine. One hopes that universal standards of description will eventually apply and that someone will take up the immense challenge to preserve records of second-hand books and manuscripts sold online. And, of course, one fears that the current model of Internet bookselling, whereby a loosely knit community of dealers caters to individual customers, may be replaced by one in which the trade is dominated by a small group of second-hand book "superstores." But too much speculation is dangerous. As Peter Kraus, proprietor of Ursus Books, noted in a recent talk at the Grolier Club about the state of the antiquarian book trade, "Tomorrow is liable to make today's prophet look like an idiot." 